\title{
Metal-loaded zeolite remediation of soils contaminated with pandrug-resistant Acinetobacter baumannii
}

\author{
Jasna Hrenović1, Svjetlana Dekić1, Jelena Dikić², Snježana Kazazić3 ${ }^{3}$ Goran Durn ${ }^{4}$, and Nevenka Rajićs \\ ${ }^{1}$ University of Zagreb Faculty of Science, Department of Biology, Zagreb, Croatia \\ ${ }^{2}$ University of Belgrade, Innovation Centre of the Faculty of Technology and Metallurgy, Belgrade, Serbia \\ ${ }^{3}$ Ruđer Bošković Institute, Division of Physical Chemistry, Zagreb, Croatia \\ ${ }^{4}$ University of Zagreb Faculty of Mining, Geology and Petroleum Engineering, Zagreb, Croatia \\ ${ }^{5}$ University of Belgrade Faculty of Technology and Metallurgy, Belgrade, Serbia
}

[Received in August 2019; Similarity Check in August 2019; Accepted in April 2020]

Due to the development of resistance to antimicrobial agents, bacterium Acinetobacter baumannii is nowadays a leading cause of nosocomial outbreaks. Clinically relevant $A$. baumannii outside hospital settings including natural soils affected by human waste represents a public-health risk for humans and animals. The aim of this study was to investigate the potential of metal-loaded zeolites to eliminate viable A. baumannii from artificially contaminated natural soils. A. baumannii isolate was subjected to the activity of natural zeolitised tuff (NZ) and Cu-modified (CuNZ) or Ag-modified zeolite (AgNZ) in wet, slightly acidic terra rossa and slightly alkaline red palaeosol. A. baumannii survived in terra rossa and red palaeosol supplemented with $1 \mathrm{wt} \%$ of $\mathrm{NZ}$ for seven days and four months, respectively. The addition of $1 \mathrm{wt} \%$ of CuNZ to terra rossa and red palaeosol shortened the survival of $A$. baumannii to three and 14 days, respectively. The addition of $0.1 \mathrm{wt} \%$ of AgNZ to both soils resulted in complete removal of viable A. baumannii within $1 \mathrm{~h}$ of contact, while the total native heterotrophic bacterial counts remained high. Since AgNZ is prepared with a simple modification of cost-effective and environmentally friendly natural zeolite, it is a promising material for the remediation of soils contaminated with pandrug-resistant $A$. baumannii.

KEY WORDS: copper; environment; natural zeolite; pathogens; public health; silver

Acinetobacter baumannii is a neutrophilic, aerobic, Gram-negative, non-sporulating bacterium (1) that has no minimal infectious dose and is capable of developing pandrug resistance (resistance to all antimicrobial agents). This is why A. baumannii is an emergent opportunistic pathogen causing nosocomial infections worldwide (2-4). Infections have also been evidenced outside hospital environments (5), but the source for these communityacquired infections has not yet been determined beyond doubt.

However, soil has scarcely been investigated as a possible source of $A$. baumannii. One $A$. baumannii strain similar to a clinical isolate was reported in palaeosol contaminated with illegally disposed human solid waste (6). Three drug-resistant isolates of $A$. baumannii were recovered from technosol developed at one dumpsite (7). However, judging by a study of $A$. baumannii in pristine soils (8), this pathogen is not native to uncontaminated soils, which clearly points to contamination (leaching) from human solid waste.

A. baumannii can survive in a wide moisture, temperature, and $\mathrm{pH}$ range (9-11), which suggests long-

Corresponding author: Jasna Hrenović, University of Zagreb, Faculty of Science, Department of Biology, Zagreb, Croatia

E-mail:jasna.hrenovic@biol.pmf.hr term persistence in soil. In a water suspension of strongly acidic palaeosol, A. baumannii survived for one day (6), while in a pH-neutral technosol it survived for 58 days (7).

As drug-resistant $A$. baumannii in soil poses a publichealth risk for humans and can also affect animals (12), we need to look for ways to remove this pathogen from contaminated soils. One of the ways to do that could be to use transition metal-containing natural zeolites due to their antibacterial properties. They have an advantage over free metal cations with antibacterial activity, since the aluminosilicate lattice of zeolites slowly releases metal cations into surroundings $(13,14)$. However, experiments with zeolites were carried out in physiological solution at $36{ }^{\circ} \mathrm{C}$ and are not applicable to the conditions in soil. To address that shortcoming, we investigated the antibacterial potential of metal-loaded zeolites directly in contaminated natural soils.

\section{MATERIALS AND METHODS}

\section{A. baumannii isolate properties}

The A. baumannii isolate (named EF7) chosen for the experiments was recovered from the effluent of a secondary wastewater treatment plant and deposited at the University 
of Zagreb Faculty of Science. This isolate is highly related to clinical isolates and is resistant to all tested antibiotics, which classifies it as pandrug-resistant $(15,16)$.

\section{Soil sampling and characterisation}

Based on results of a previous investigation (17), we used two soil samples representative of slightly acidic and alkaline soil from Istria, Croatia - terra rossa and red palaeosol from Cretaceous limestone - dug from the upper $30 \mathrm{~cm}$ of $50 \mathrm{~cm}$ deep pits. Samples were aseptically collected in sterile plastic bags and analysed in the laboratory within $24 \mathrm{~h}$ of collection.

Soil $\mathrm{pH}$ value was measured with a WTWSenTix81 electrode (WTW, Weilheim, Germany) after triplicate suspension in distilled water $(1: 2.5 \mathrm{wt} / \mathrm{v})$. The procedures for chemical (ICP-ES/MS following a lithium borate fusion and dilute nitric digestion) and mineralogical analyses (X-ray powder diffraction of $<2 \mathrm{~mm}$ and $<2 \mu \mathrm{m}$ fractions) were described in detail in Durn et al. (18).

\section{Preparation of metal-loaded zeolites}

Natural zeolitised tuff (NZ) was obtained from a Zlatokop sedimentary deposit in Serbia and consisted of $73 \%$ clinoptilolite, $14 \%$ plagioclase, and $13 \%$ quartz (wt). To load NZ with metals, we used the ion-exchange procedure described in our earlier study (14). Briefly, it consisted of the following steps: 1 ) conversion of $\mathrm{NZ}$ into Na-enriched form (NaNZ) by treating NZ with $2 \mathrm{~mol} / \mathrm{L}$ of $\mathrm{NaCl}$ solution at $25^{\circ} \mathrm{C}$ for $48 \mathrm{~h}$; 2) treatment of $\mathrm{NaNZ}$ with $6 \mathrm{mmol} / \mathrm{L}$ of $\mathrm{Cu}\left(\mathrm{NO}_{3}\right)_{2}$ or $\mathrm{AgNO}_{3}$ solution in a water bath at $25^{\circ} \mathrm{C}$ for $24 \mathrm{~h}$; and 3 ) recovering of the metal-containing products (CuNZ and AgNZ) by filtration.

\section{Leaching test}

The leaching of cations from zeolites to soil samples is technically hard to track. Moreover, our previous investigation (13) showed negligible leaching of $\mathrm{Cu}^{2+}$ from $\mathrm{CuNZ}$ into the water medium. This is why we investigated only $\mathrm{Ag}^{+}$leaching in this study. One gram of red palaeosol was supplemented with $1 \mathrm{mg}(0.1 \mathrm{wt} \%)$ of AgNZ and added to $100 \mathrm{~mL}$ of autoclaved commercially available spring water and left in the dark at $25{ }^{\circ} \mathrm{C}$ for $1 \mathrm{~h}$. The solid was separated from water by filtration through $0.45 \mu \mathrm{m}$ syringe filters and the concentration of the leached Ag determined in water solution by atomic absorption spectrophotometer (AAS Varian, Spectra AA 55b, Agilent Technologies, Santa Clara, CA, USA)

\section{Experimental setup and bacterial counting}

The $A$. baumannii isolate was grown on CHROMagar Acinetobacter supplemented with CR102 (CHROMagar, Paris, France) and $15 \mathrm{mg} / \mathrm{L}$ of cefsulodin (Sigma-Aldrich, St. Louis, MO, USA) at $36{ }^{\circ} \mathrm{C}$ for $24 \mathrm{~h}$. The biomass was suspended in $300 \mathrm{~mL}$ of autoclaved commercial spring water. Based on preliminary experiments, this suspension was used to adjust soil moisture to their maximum waterholding capacity of $30 \mathrm{wt} \%$.

Both soils were distributed in $100 \mathrm{~g}$ quadruplicate samples to laboratory glasses. A. baumannii suspension was added gradually by mixing it in with a sterile spatula. The content of eight glasses was mixed with $1 \mathrm{~g}$ of NZ, CuNZ, or $\mathrm{AgNZ}$ or $0.1 \mathrm{~g}$ of AgNZ. These experimental glasses were covered with parafilm and incubated in the dark at $25^{\circ} \mathrm{C}$ until all viable $A$. baumannii disappeared. Soil moisture was kept constant (30 wt $\%$ ) in all systems by adding autoclaved spring water as needed, which was determined by weekly gravimetrical measurements of soil moisture (by drying soil at $105^{\circ} \mathrm{C}$ to constant weight) in a system supplemented with NZ.

At the beginning of the experiment and at specified time points (Figures 1 and 2), the soil samples were mixed well and subsamples taken for bacteriological analysis in triplicate. One gram of wet soil was suspended in sterile
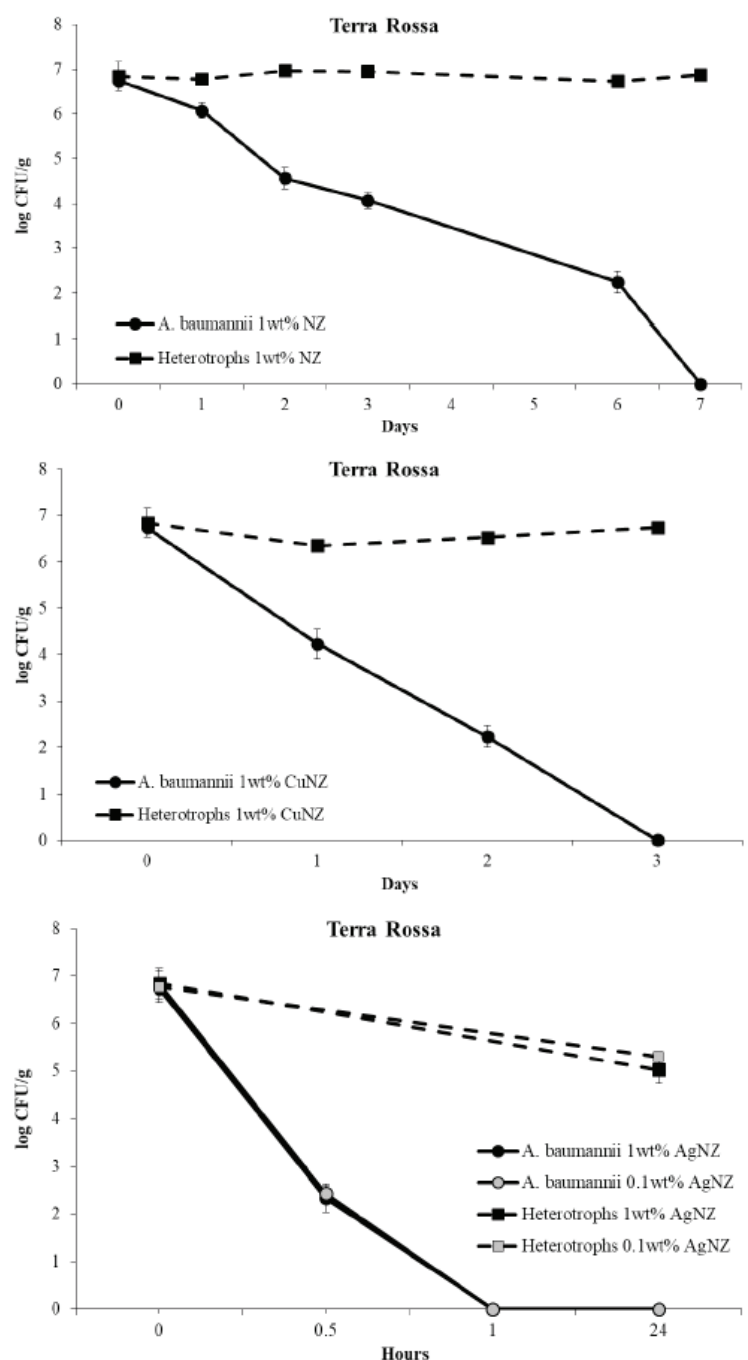

Figure 1 Removal of $A$. baumannii from slightly acidic terra rossa (pH 5.40) supplemented with $1 \mathrm{wt} \%$ of natural zeolitised tuff(NZ) or $1 \mathrm{wt} \%$ of $\mathrm{Cu}$-loaded NZ (CuNZ), or 1 or $0.1 \mathrm{wt} \%$ of Ag-loaded $\mathrm{NZ}$ (AgNZ). Bacterial counts represent averages of triplicate counts \pm standard deviation. The detection limit was $1 \mathrm{CFU} / \mathrm{g}$ 
physiological solution by vortexing at $45 \mathrm{~Hz}$ for $3 \mathrm{~min}$ and then passed through sterile membrane filters directly when bacterial concentrations were low or diluted decimally and inoculated on bacteriological media when the concentrations were sufficient for dilution.

Total native heterotrophic bacteria were counted on nutrient agar (Biolife, Milan, Italy) after incubation at $22^{\circ} \mathrm{C}$ for 72 h. A. baumannii was cultivated on selective CHROMagar Acinetobacter medium supplemented with CR102 and cefsulodin after incubation at $36{ }^{\circ} \mathrm{C}$ for $48 \mathrm{~h}$. This medium, intended for the cultivation of carbapenemresistant bacteria, allowed for selective growth of carbapenem-resistant $A$. baumannii. This medium allows development of other Gram-negative bacteria resistant to $\beta$-lactam antibiotics (carbapenems and cephalosporins), but the large, circular, convex, smooth, red colonies of $A$. baumannii with a paler central area are clearly distinct from other bacterial species (19). Even so, we did not notice any interference of other bacteria. Native bacteria did not hinder A. baumannii counting.

Bacterial colonies were identified on whole cells with matrix-assisted laser desorption/ionisation - time of flight mass spectrometry (MALDI-TOF MS, software version 3.0, Microflex LT, Bruker Daltonics, Billerica, MA, USA). Randomly chosen colonies developed on CHROMagar Acinetobacter were confirmed as A. baumannii. Randomly chosen, morphologically different colonies of heterotrophic bacteria developed on nutrient agar (four plates per system) were also identified.

A. baumannii and total heterotrophic bacterial counts were expressed as log colony forming units (CFU) per one $\mathrm{g}$ of wet soil. The drop in A. baumannii count was calculated at the end of the experiments by subtracting bacterial count at the end from the baseline count $[\log \mathrm{CFU} / \mathrm{g}($ start $)-\log$ $\mathrm{CFU} / \mathrm{g}($ end $)]$.

\section{Statistical analysis}

Statistical significance $(\mathrm{p}<0.05)$ of the difference between the baseline and end bacterial counts was established with Student's $t$-test for independent variables using Statistica 13.3 (TIBCO Software, Inc., Palo Alto, CA, USA).

\section{RESULTS AND DISCUSSION}

\section{Characteristics of soils and modified zeolites}

Terra rossa was slightly acidic ( $\mathrm{pH} 5.40 \pm 0.21$ ), and red palaeosol slightly alkaline ( $\mathrm{pH} 8.43 \pm 0.14)$. Both soils were dominated by quartz and clay minerals (illitic material and mica, kaolinite and mixed-layer clay minerals), followed by plagioclase, $\mathrm{K}$ feldspar, haematite, and goethite. Unlike terra rossa, red palaeosol also contained chlorite, $14 \AA$ clay minerals, dolomite and calcite. Terra rossa and red palaeosol had similar chemical composition of both major oxides and trace elements. The only difference was the higher content of $\mathrm{MgO}$ and $\mathrm{CaO}$ in red palaeosol, which corresponds to its mineral composition (presence of calcite and dolomite) and slight alkalinity.

The samples of modified zeolites contained similar amounts of metal cations per gram of dry sample: $0.37 \mathrm{mmol} \mathrm{Cu}^{2+}(\mathrm{CuNZ})$ or $0.50 \mathrm{mmol} \mathrm{Ag}^{+}(\mathrm{AgNZ})$.

Remediation of terra rossa contaminated with A. baumannii

In terra rossa supplemented with $1 \mathrm{wt} \%$ of NZ (Figure 1) A. baumannii survived for seven days, when its count dropped from of the baseline of $6.7 \log \mathrm{CFU} / \mathrm{g}$ to below the detection limit (1 CFU/g). No statistically significant drop was observed for the native heterotrophic bacteria over these seven days. As NZ does not exhibit antimicrobial activity (14), this drop in $A$. baumannii count can be attributed to soil acidity, to which $A$. baumannii as a neutrophilic species is not adapted.
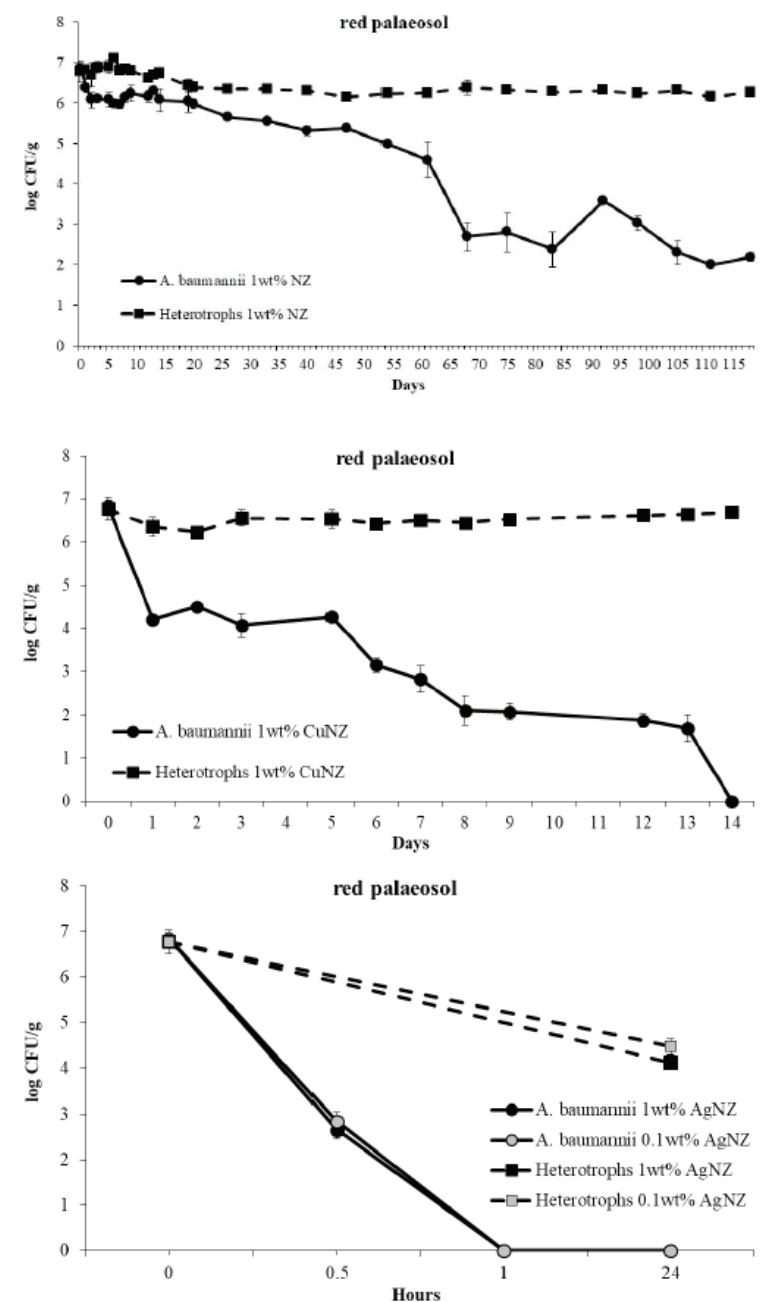

Figure 2 Removal of $A$. baumannii from slightly alkaline red palaeosol ( $\mathrm{pH} 8.43$ ) supplemented with $1 \mathrm{wt} \%$ of natural zeolitised tuff (NZ) or $1 \mathrm{wt} \%$ of Cu-loaded NZ (CuNZ), or 1 or $0.1 \mathrm{wt} \%$ of Ag-loaded NZ (AgNZ). Bacterial counts represent averages of triplicate counts \pm standard deviation. The detection limit was $1 \mathrm{CFU} / \mathrm{g}$ 
The addition of $1 \mathrm{wt} \%$ CuNZ (Figure 1) significantly accelerated the removal of $A$. baumannii to only three days of contact, while the native heterotrophic bacteria were not affected. This suggests a selective bactericidal effect of CuNZ on A. baumannii.

The addition of $1 \mathrm{wt} \%$ of AgNZ (Figure 1) resulted in complete removal within $1 \mathrm{~h}$ of contact. The same result was achieved with $0.1 \mathrm{wt} \%$ of AgNZ. Although this effect was accompanied by a statistically significant reduction of heterotrophic bacteria, their count was still high (5.2 $\pm 0.2 \log \mathrm{CFU} / \mathrm{g})$ after $24 \mathrm{~h}$ of contact.

\section{Remediation of red palaeosol contaminated with A. baumannii}

In red palaeosol supplemented with $1 \mathrm{wt} \%$ of $\mathrm{NZ}$ (Figure 2) A. baumannii count dropped significantly compared to baseline, but viable cells were detected throughout the four months of monitoring $(2.2 \log \mathrm{CFU} / \mathrm{g})$ The bacteria did not multiply, probably due to low soil organic carbon content (0.215 wt\%). An earlier study (11) showed that $A$. baumannii survived for a long time (150 days) in spring water with a $\mathrm{pH}$ of 8.1 , which is very close to the $\mathrm{pH}$ of our red palaeosol samples $(8.43 \pm 0.14)$. As moisture was kept to the maximum water holding capacity, desiccation can be eliminated as the cause of $A$. baumannii count drop. Anaerobic conditions can also be excluded, as the soil layer in glasses was not thicker than $3 \mathrm{~cm}$ and was regularly stirred. Rises and falls in A. baumannii counts observed from day 68 on could be explained by the "bust and boom" survival strategy, where weak cells die to provide sustenance for the remaining cells (9). However, the difference between the $32 \%$ survival in red palaeosol in this study and $>90 \%$ survival in spring water in our earlier study (11) suggests that nutrient deprivation is not the only cause of lower $A$. baumannii survival in red palaeosol. Perhaps it was the presence of $\mathrm{Fe}$ in wet red palaeosol that contributed to the drop in A. baumannii count via oxidative stress (20).

The difference in A. baumannii survival between red palaeosol (four months) and terra rossa (seven days), both treated with NZ, is clearly owed to their difference in soil $\mathrm{pH}$ (8.43 vs 5.40, respectively), which suggests that priority in soil treatment should be given to slightly alkaline soils such as red palaeosol.

The addition of $1 \mathrm{wt} \%$ of CuNZ (Figure 2) completely removed $A$. baumannii after 14 days without affecting native heterotrophic bacteria by the end of the experiment.

The addition of 1 or $0.1 \mathrm{wt} \%$ of AgNZ (Figure 2) removed the entire $A$. baumannii population within $1 \mathrm{~h}$. Heterotrophic bacterial count dropped significantly but was still $4.3 \pm 0.2 \log \mathrm{CFU} / \mathrm{g}$ after $24 \mathrm{~h}$ of monitoring.

Considering the long survival of $A$. baumannii in red palaeosol (more than four months), we feel that the promising activity of AgNZ in slightly alkaline red palaeosol deserves more attention than in acidic terra rossa. AgNZ particles are bactericidal in direct contact with bacteria in soil and through leached Ag cations $(14,21)$. However, this antibacterial activity will depend on soil chemistry and the distribution of AgNZ particles and their contact with bacteria in soil. In our leaching test with red palaeosol $0.038 \mathrm{mg} / \mathrm{L}$ of Ag leached from $0.1 \mathrm{wt} \%(1 \mathrm{mg} / \mathrm{g})$ of AgNZ added to the soil. This concentration of leached Ag was enough to eliminate $6.8 \log \mathrm{CFU} / \mathrm{g}$ of $A$. baumannii.

Table 1 Native soil heterotrophic bacterial isolates determined with MALDI-TOF MS in fresh red palaeosol before and at the end of treatment with $1 \mathrm{wt} \%$ of $\mathrm{NZ}$ or $\mathrm{CuNZ}$ or $\mathrm{AgNZ}$

\begin{tabular}{|c|c|c|c|c|}
\hline Isolate & Fresh soil & NZ & CuNZ & AgNZ \\
\hline Arthrobacter sp. & 6 & 1 & 1 & \\
\hline Arthrobacter oxydans & & 4 & 1 & \\
\hline Arthrobacter scleromae & & 1 & & \\
\hline Arthrobacter polychromogenes & & 1 & & \\
\hline *Bacillus sp. & 2 & & & 6 \\
\hline *Bacillus cereus & & & & 2 \\
\hline *Bacillus megaterium & & & & 1 \\
\hline *Bacillus thuringiensis & & & & 1 \\
\hline *Brevibacillus sp. & & & & 1 \\
\hline Burkholderia sp. & 1 & & & \\
\hline Burkholderia caledonica & 1 & & & \\
\hline *Paenibacillus sp. & 2 & & & 2 \\
\hline Pseudomonas sp. & 1 & & & \\
\hline *Streptomyces sp. & 2 & & & \\
\hline *Streptomyces chartreusis & & 1 & 1 & \\
\hline Variovorax sp. & & & 1 & \\
\hline
\end{tabular}


Table 1 shows native heterotrophic bacteria identified in red palaeosol before and after treatment with NZ, CuNZ, or AgNZ. Treatment with NZ and CuNZ left both sporeforming (Bacillus, Brevibacillus, Paenibacillus, Streptomyces) and nonspore-forming genera (Arthrobacter, Burkholderia, Pseudomonas) alive, while only sporogenic isolates survived the treatment with AgNZ.

Ag cations exert bactericidal effects by blocking the enzymatic machinery of bacterial cells (22). There are concerns about A. baumannii surviving in hostile environments for a long time by going dormant, that is, by retaining their viability but not culturability, which may affect cell counting. A recent study (10) has showed that $A$. baumannii could lose culturability if kept at $37^{\circ} \mathrm{C}$ for a long time. However, this phenomenon of cell dormancy did not occur at $20^{\circ} \mathrm{C}$. Our experiments simulated environmental temperature of $25^{\circ} \mathrm{C}$, and $\mathrm{AgNZ}$ showed its effects quickly, within $1 \mathrm{~h}$, which clearly excludes the possibility that the cells went dormant (non-culturable) but remained viable.

With its almost instant bactericidal effect against $A$. baumannii at very low concentrations, AgNZ could be applied in contaminated soils without negative impact on native bacterial populations. Furthermore, Ag cations stick to negatively charged soil particles (23), which minimises the possibility of their further leaching from soil, migration into groundwater, and toxic effects in the environment.

\section{CONCLUSIONS}

The addition of AgNZ to soil resulted in removal of $6.8 \log \mathrm{CFU} / \mathrm{g}$ of viable $A$. baumannii within $1 \mathrm{~h}$ of contact. AgNZ particles in the mass fraction of $0.1 \mathrm{wt} \%(1 \mathrm{~g}$ per $1 \mathrm{~kg}$ of soil) could easily be dispersed onto soil contaminated with $A$. baumannii. Since AgNZ is prepared with a simple modification of cost-effective and environmentally friendly natural zeolite, it is a promising material for the remediation of soils contaminated with pandrug-resistant $A$. baumannii.

\section{Acknowledgements}

This research was supported by the Croatian Science Foundation (project no. IP-2014-09-5656).

\section{Conflicting interests}

None to declare.

\section{REFERENCES}

1. Garrity GM, Brenner DJ, Krieg NR, Staley JT. Bergey's Manual of Systematic Bacteriology. $2^{\text {nd }}$ ed. Vol 2: The Proteobacteria, Part B: The Gammaproteobacteria. New York: Springer; 2005.

2. Towner KJ. Acinetobacter: an old friend, but a new enemy. J Hosp Infect 2009;73:355-63. doi: 10.1016/j. jhin.2009.03.032
3. Boucher HW, Talbot GH, Bradley JS, Edwards JE, Gilbert D, Rice LB, Scheld M, Spellberg B, Bartlett J. Bad bugs, no drugs: no ESKAPE! An update from the Infectious Diseases Society of America. Clin Infect Dis 2009;48:1-12. doi: $10.1086 / 595011$

4. Roca I, Espinal P, Vila-Farres X, Vila J. The Acinetobacter baumannii oxymoron: commensal hospital dweller turned pan-drug-resistant menace. Front Microbiol 2012;3:148. doi: 10.3389/fmicb.2012.00148

5. Dexter C, Murray GL, Paulsen IT, Peleg AY. Communityacquired Acinetobacter baumannii: clinical characteristics, epidemiology and pathogenesis. Expert Rev Anti Infect Ther 2015;13:567-73. doi: 10.1586/14787210.2015.1025055

6. Hrenovic J, Durn G, Goic-Barisic I, Kovacic A. Occurrence of an environmental Acinetobacter baumannii strain similar to a clinical isolate in paleosol from Croatia. Appl Environ Microbiol 2014;80:2860-6. doi: 10.1128/AEM.00312-14

7. Hrenovic J, Durn G, Seruga Music M, Dekic S, TroskotCorbic T, Skoric D. Extensively and multi drug-resistant Acinetobacter baumannii recovered from technosol at a dump site in Croatia. Sci Total Environ 2017;607-608:1049-55. doi: 10.1016/j.scitotenv.2017.07.108

8. Hrenovic J, Ivankovic T, Durn G, Dekic S, Kazazic S Kisic I. Presence of carbapenem-resistant bacteria in soils affected by illegal waste dumps. Int J Environ Heal Res 2019;29:154 63. doi: 10.1080/09603123.2018.1522423

9. Bravo Z, Orruño M, Parada C, Kaberdin VR, Barcina I, Arana I. The long-term survival of Acinetobacter baumannii ATCC $19606^{\mathrm{T}}$ under nutrient-deprived conditions does not require the entry into the viable but non-culturable state. Arch Microbiol 2016;198:399-407. doi: 10.1007/s00203-0161200-1

10. Bravo Z, Orruño M, Navascues T, Ogayar E, Ramos-Vivas J, Kaberdin VR, Arana I. Analysis of Acinetobacter baumannii survival in liquid media and on solid matrices as well as effect of disinfectants. J Hosp Infect 2019;103:e4252. doi: 10.1016/j.jhin.2019.04.009

11. Dekic S, Hrenovic J, Ivankovic T, van Wilpe E. Survival of ESKAPE pathogen Acinetobacter baumannii in water of different temperatures and $\mathrm{pH}$. Water Sci Technol 2018;78:1370-6. doi: 10.2166/wst.2018.409

12. Ewers C, Klotz P, Leidner U, Stamm I, Prenger-Berninghoff E, Göttig S, Semmler T, Scheufen S. OXA-23 and ISAba1OXA-66 class D $\beta$-lactamases in Acinetobacter baumannii isolates from companion animals. Int J Antimicrob Agents 2017;49:37-44. doi: 10.1016/j.ijantimicag.2016.09.033

13. Hrenovic J, Milenkovic J, Ivankovic T, Rajic N. Antibacterial activity of heavy metal-loaded natural zeolite. J Hazard Mater 2012;201-202:260-4. doi: 10.1016/j.jhazmat.2011.11.079

14. Hrenovic J, Milenkovic J, Goic-Barisic I, Rajic N. Antibacterial activity of modified natural clinoptilolite against clinical isolates of Acinetobacter baumannii. Micropor Mesopor Mater 2013;169:148-52. doi: 10.1016/j. micromeso.2012.10.026

15. Goic-Barisic I, Seruga Music M, Kovacic A, Tonkic M, Hrenovic J. Pan drug-resistant environmental isolate of Acinetobacter baumannii from Croatia. Microb Drug Resist 2017;23:494-6. doi: 10.1089/mdr.2016.0229

16. Higgins PG, Hrenovic J, Seifert H, Dekic S. Characterization of Acinetobacter baumannii from water and sludge line of secondary wastewater treatment plant. Water Res 2018;140:261-7. doi: 10.1016/j.watres.2018.04.05 
17. Zhang J, Rolf C, Wacha L, Tsukamoto S, Durn G, Frechen $\mathrm{M}$. Luminescence dating and palaeomagnetic age constraint of a last glacial loess-palaeosol sequence from Istria, Croatia. Quatern Int 2018;494:19-33. doi: 10.1016/j. quaint.2018.05.045

18. Durn G, Wacha L, Bartolin M, RolfC, Frechen M, Tsukamoto S, Tadej N, Husnjak S, Li Y, Rubinić V. Provenance and formation of the red palaeosol and lithified terra rossa-like infillings on the Island of Susak: A high-resolution and chronological approach. Quatern Int 2018;494:105-29. doi: 10.1016/j.quaint.2017.11.040

19. Hrenovic J, Goic-Barisic I, Kazazic S, Kovacic A, Ganjto M, Tonkic M. Carbapenem-resistant isolates of Acinetobacter baumannii in a municipal wastewater treatment plant, Croatia, 2014. Euro Surveill 2016;21:30195. doi: 10.2807/1560-7917.ES.2016.21.15.30195
20. Touati D. Iron and oxidative stress in bacteria. Arch Biochem Biophys 2000;373:1-6. doi: 10.1006/abbi.1999.1518

21. Kwakye-Awuah B, Williams C, Kenward MA, Radecka I. Antimicrobial action and efficiency of silver-loaded zeolite X. J Appl Microbiol 2008;104:1516-24. doi: 10.1111/j.1365-2672.2007.03673.x

22. Bovenkamp GL, Zanzen U, Krishna KS, Hormes J, Prange A. X-Ray absorption near-edge structure (XANES) spectroscopy study of the interaction of silver ions with Staphylococcus aureus, Listeria monocytogenes and Escherichia coli. Appl Environ Microbiol 2013;79:6385-90. doi: 10.1128/AEM.01688-13

23. Rahmatpour S, Shirvani M, Mosaddeghi MR, Bazarganipour M. Retention of silver nano-particles and silver ions in calcareous soils: influence of soil properties. J Environ Manage 2017;15:136-45. doi: 10.1016/j.jenvman.2017.01.062

Zeoliti modificirani metalima u remedijaciji tala zagađenih bakterijom Acinetobacter baumannii otpornom na antibiotike

Bakterija Acinetobacter baumannii u današnje je vrijeme vodeći uzročnik bolničkih infekcija, ponajprije zbog brzoga razvoja otpornosti te bakterije na antimikrobne lijekove. Klinički značajni $A$. baumannii izvan bolničkoga okružja, kao što su prirodna tla pod utjecajem ljudskoga otpada, javnozdravstveni su rizik za ljude i životinje. Cilj ovoga rada bio je istražiti potencijal zeolita modificiranih metalima za uklanjanje vijabilnih $A$. baumannii iz umjetno zagađenih prirodnih tala. Izolat $A$. baumannii u vlažnoj blago kiseloj terra rossa (pH 5,40) i blago lužnatom crvenom paleotlu (pH 8,43) podvrgnut je djelovanju prirodnoga zeolitnoga tufa (NZ) te NZ-a modificiranoga bakrom (CuNZ) ili srebrom (AgNZ). U slučaju dodatka $1 \mathrm{wt} \%$ NZ-a, A. baumannii je preživio u terra rossa sedam dana, a u crvenom paleotlu čak četiri mjeseca. Dodatak $1 \mathrm{wt} \%$ CuNZ-a u tla skratio je preživljavanje $A$. baumannii na tri dana u terra rossa i 14 dana u crvenom paleotlu. Dodatak samo 0,1 wt\% AgNZ-a u tla rezultirao je kompletnim uklanjanjem vijabilnih $A$. baumannii tijekom jednoga sata kontakta, pri čemu je brojnost ukupnih heterotrofnih bakterija, prirodno prisutnih u tlu, ostala visoka. Cestice AgNZ-a pripremaju se jednostavnom modifikacijom jeftinoga i okolišno prihvatljivoga prirodnoga zeolita. Mala koncentracija ( $1 \mathrm{~g} \mathrm{AgNZ-a} \mathrm{po} 1 \mathrm{~kg}$ tla) mogla bi se jednostavno raspršiti po tlu koje je zagađeno bakterijom $A$. baumannii. Stoga je AgNZ obećavajući materijal za remedijaciju tala zagađenih tom bakterijom koja je otporna na sve dostupne antibiotike.

KLJUČNE RIJEČI: bakar; okoliš; patogeni; prirodni zeolit; srebro; zdravstvena zaštita 